\title{
THE EARLY MEDIEVAL VILLAGE OF MORAWY: A GRAVE FIELD FROM THE 11 $^{\mathrm{TH}}$ CENTURY $^{1}$
}

\author{
WCZESNOSREDNIOWIECZNE MORAWY: CMENTARZYSKO Z XI WIEKU
}

\begin{abstract}
This article deals with the issues of an $11^{\text {th }}$ century grave field in Morawy village in Kuyavia. In the first Piast times, the area was an integral part of the dynasty's dominion. Discovered in the 1930s, the grave field is of great importance from the point of view of considerations of ethnically foreign settlements in Poland.
\end{abstract}

Keywords: Morawy, grave field, captives, gold knob, Kuyavia.

In 1937, rescue research was carried out in Morawy village (now Dobre commune, Radziejów county, Kuyavian-Pomeranian region in Poland). The research was headed by Stanisław Madajski and the results published by Konrad Jażdżewski in 1937 in the form of a brief report (Jażdżewski 1937, s. 126-129). In the subsequent years, there were several references to the pre-WWII excavations by S. Madajski (Rajewski 1958, p. 198, 199, 200; Musianowicz 1969, p. 355-360; Zoll-Adamikowa 1975, p. 175-176).

In the literature on the subject, the discovered burial sites, together with their antiquities and the grave field chronology have only been partially discussed. Therefore, there is a need for a detailed presentation of the research from 1937, especially as the results of S. Madajski's rescue research have been published only in part. In the course of an archive search query in the State Archaeological Museum (SAM) in Warsaw it turned out that a large part of the relevant documentation has survived; the same holds true for the artefacts. The separated historic

\footnotetext{
*Wydział Historyczny UAM, ul. Umultowska 89D, 61-614 Poznań, m_danielewski@tlen.pl.

1 Research work financed as part of a programme of the Minister of Science and Higher Education "The National Programme for the Development of Humanities" in 2014-2019; project no. 0040/ NPRH3/H11/82/2014. The Polish version of the article on the grave field in Morawy was published in 2017 in Historia Slavorum Occientis akademic journal.
} 


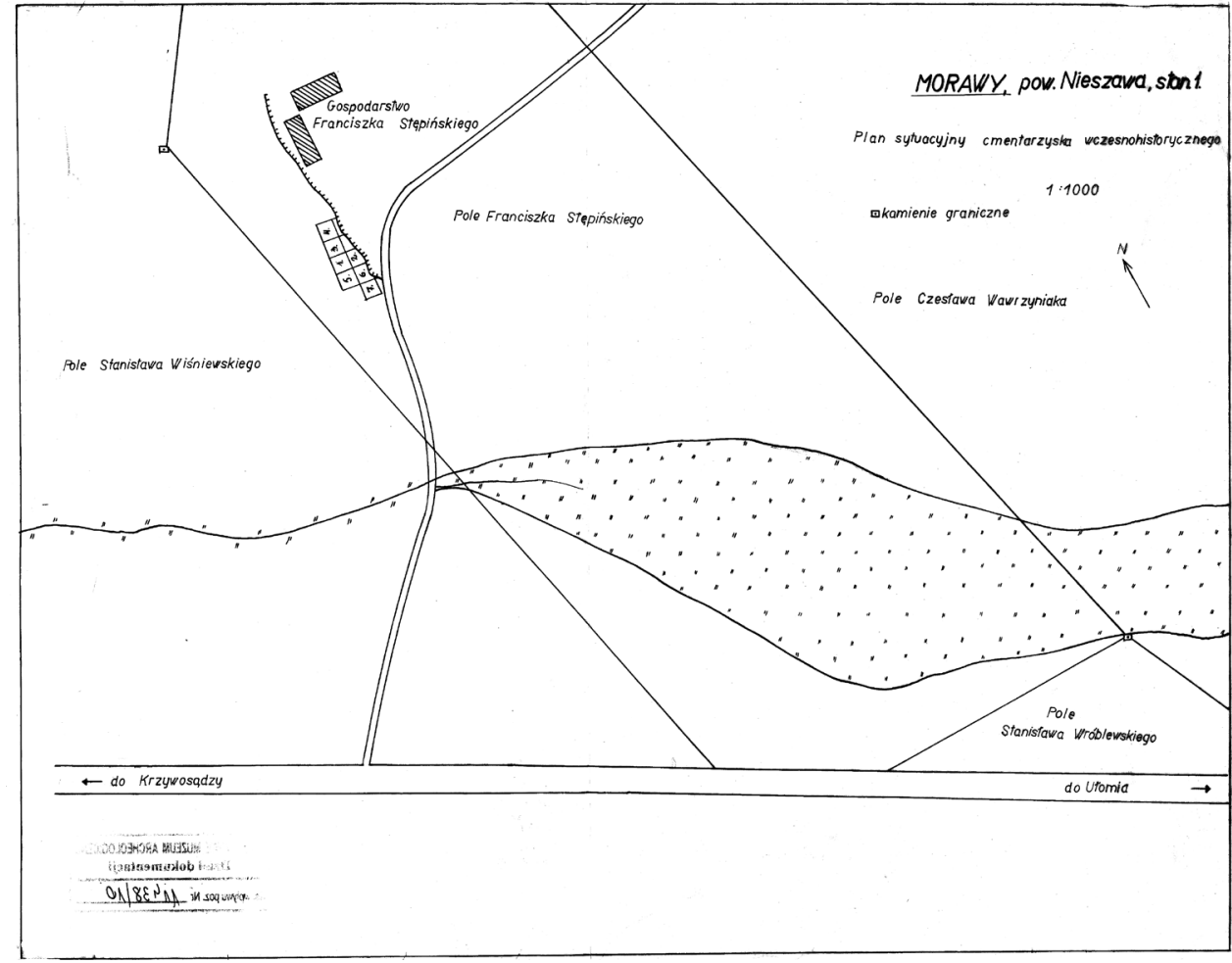

Fig. 1. Site 1 plan. Collection of the State Archaeological Museum in Warsaw (further referred to as the SAM Warsaw Collection)

objects are stored in the SAM's headquarters in Warsaw, while the ceramic material and bones are located in the Storage and Study Facilities in Rybno ${ }^{2}$.

Before I proceed with the considerations, I need to briefly discuss the state of knowledge of the early medieval settlement in Morawy as part of the AZP 46-43 area. The village has been rather poorly researched from the point of view of an early Middle Ages settlement. The archaeological works have been typically limited to surface explorations. The discussed grave field (archaeological site no. 1) is the best recognised early medieval site $^{3}$ which was examined before WWII and verified with respect to the excavations in 2015. It is worth noting that the necropolis has been classified as multi-culture site no. 1. The oldest discovered traces of settlement are related to Neolithic communities: the Funnelbeaker culture and the

${ }^{2}$ I would like to thank Wojciech Brzeziński, Ph.D., director of the State Archaeological Museum, for providing me with an opportunity to use the facilities' collections and to develop photographic documentation of the historic objects and archived documents. I would also like to thank Andrzej Piotrowski and Adam Kulesza who helped me to find the collection.

${ }^{3}$ Each time, I quote the number of the archaeological site in a location. 
Corded Ware culture. On site no. 1, the Bronze Age is represented by ceramic material from the Lusatian culture. On the other hand, the youngest historical settlement is related to the late Middle Ages and the early modern period.

On top of the aforementioned necropolis, in Morawy village, traces of other settlements have also been identified. As part of the Archaeological Image of Poland, a project carried out in this area in the 1980s, 5 settlement traces were registered (sites no. 6, 7, 12, 15, 24) together with two hamlets (sites no. 20 and 23). A majority of these sites were dated back to the E-F phase (sites no. 6, 12, $20,23,24)$; the chronology of the remaining ones was referred to as proto-Polish (Obszar 46-43). Two elements of medieval settlement classified as hamlets i.e. sites no. 20 and 23, located to the north and the north-west of the grave field, have also been poorly examined (Karta AZP, Stanowisko 20; Karta AZP Stanowisko 23). Therefore, they cannot be directly related to the early medieval grave field operating in the $11^{\text {th }}$ century in the village of Morawy.

The name Morawy (Moravia) poses a separate research problem; in literature on the subject, Zdzisław Rajewski attempted to relate the name of the village to prisoners of war from Moravia or the old Prussian areas. In his reasoning, the archaeologist referred to a cremation grave (grave no. 2) which, according to Rajewski, may indicate burial of war captives (Rajewski 1958, p. 199). It is worth adding that the issue of captive place names like Morawy, Prusy (Prussia) or Pomorzany (Pomerania) in Poland has been discussed many times in the literature on the subject (Kozierowski 1922, p. 47; Modrzewska 1969, p. 345-383; Modzelewski 2000, p. 132).

The hypothesis constructed around the village of Morawy and the Moravians was further supported by Krystyna Musianowicz, who described a bronze, gold-plated knob discovered in the village in question. Analogous historic artefacts were found in Nitra in Moravia. The archaeologist decided that the name Morawy came from the place of origin of the captured individuals, while the knob could have been brought with them in the second half of the $10^{\text {th }}$ century, or later as an element of contact with their native land (Musianowicz 1969, s. 358-359). A possible acceptance of the hypotheses of the captive origin of the population would connect with the soil conditions in this area. Having recognised the concurrence of the locations of ancillary settlements in Kuyavia enjoying the best soil (Danielewski 2015, p. 60-61), it would be logical to locate captives in areas with poor soil conditions. This is because the status of captives was far lower than that of the ancillary population. Karol Modzelewski emphasized that slaves would settle in poorly populated or unpopulated areas (Modzelewski 2000, p. 72) but then Kuyavia is not such an area. On the other hand, in the region of Moravia, poor soil prevails unlike the humus-rich soil in the Kuyavian Radziejów or Dobre (Kolberg 1962, p. 21; Hoff 1998, p. 7). If that was the case, the location of captives in Morawy would be justified. An area with poor soil, most probably unpopulated or very poorly populated (as confirmed with observations from the aforementioned surface 
explorations), would be the right location for captives. What is more, Kuyavia was very far away from Nitra in Moravia; to some extent, this would solve the issue of fugitives which must have been recruited from slaves (Modzelewski 2000, p. 123).

Written sources clearly indicate that belligerent expeditions organised in the first half of the $11^{\text {th }}$ century by the Piast dynasty rulers provided spoils in the form of captives. The bishop of Merseburg briefly commented on one of Mieszko II's raids on Oldřich's Czech dominion: Dum haec aguntur, Miseco, Bolizlavi filius, Boemiam absencia Othelrici ducis sui minus solito repugnantem cum X legionibus invadens, duos dies predatur eandem et cum innumerabili captivorum multitudine reversus patrem gaudiis replevit inmens (Thietmar 1935, lib. VII, cap. 59, p. 472). The description clearly indicates that Mieszko II pillaged the Czech lands and returned with a large number of captives. Thietmar the chronicler did not mention spoils other than humans captured during the raid. This is evidence that captives were the most valuable bounty.

Attention should also be paid to the 1030s and an altogether different situation: at that time, princes from the Rurik and the Přemyslid dynasties raided the Piast dominion and seized locals. A case in point is a raid on Mieszko II's land headed by Yaroslav the Wise and Mstislav in 1031: "В льто 6539. Ярославъ и Мьстиславъ собраста вой многъ, идоста на Ляхы, и заяста грады червеньскыя опять, и повоеваста Лядьскую землю, и многи ляхы приведоста, и раздьливша я. Ярославъ посади своя по Ръси, и суть до сего дне” (Повесть временных лет 1950, p. 101). This coverage clearly indicates that numerous captives were brought to Rus, who later on settled along the river Rosia.

A similar description, related to a raid on the Polish dominion by Bretislav, is reflected in Kosmas' text: Cumque pervenissent ad castrum Gdec, castellani et simul qui illuc confugerant villani non valentes ferre impetum ducis exeunt ei obviam auream gestantes virgam, quod erat signum dedicionis, et ut eos pacifice cum suis peccoribus et ceteris rerum appendiciis transferat in Boemiam, suppliciter rogant. Quorum dux petitionibus adquiescens, postquam perduxit eos in Boemiam, dat eis partem silve, que vocatur Cirnin, non modicam constituens eis unum ex ipsis prefectum et iudicem et decernit, ut sub lege, quam in Polonia habuerant, tam ipsi quam eorum posteri in sempiternum vivant, atque nomine ab urbe derivato usque hodie nuncupantur Gedcane (Kosmas 1923, lib. II, cap. 2, p. 83-84). The chronicler described the mechanism of relocating people, this time from the Piast domain to the area under Přemyslid's rule. These three selected examples show that people were relocated and the outflow of people could be dramatic as it was in the case of the Piast dominion in the 1030s (Danielewski 2014, p. 149-150).

Let me sum up this part of the considerations by saying that the question of whether the discussed grave field can be related to captives from Moravia is an open one. It is also hard to say if the name Morawy was used as early as in the Middle Ages. It certainly cannot be found in the written sources. This fact calls for caution in drawing ultimate conclusions. 


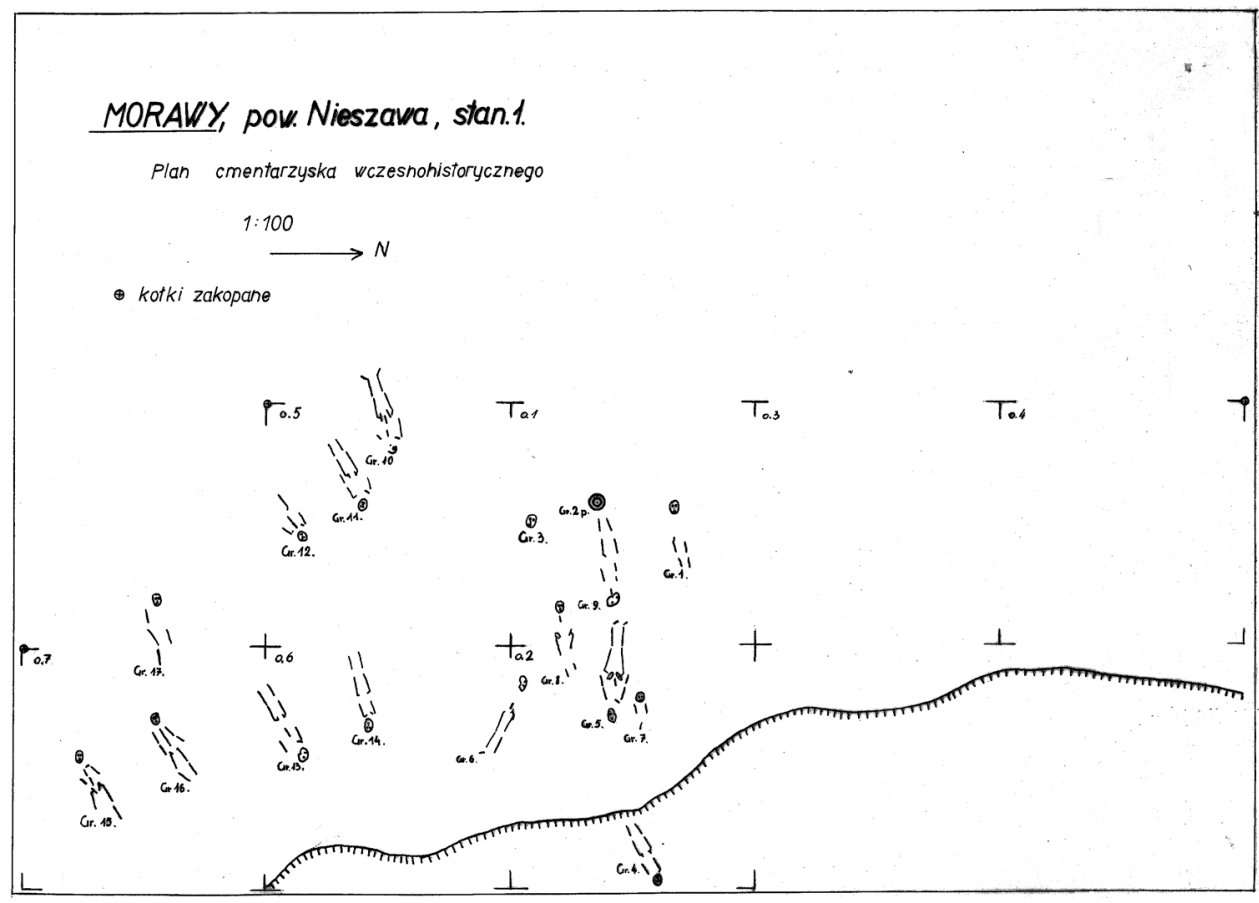

Fig. 2. Plan: Morawy grave field, site 1.SAM Warsaw collection

As part of the works conducted in 1937, seventeen graves were identified including a cremation one (Jażdżewski 1937, p. 127). While some descriptions include information that only eleven burials were uncovered (Zielonka 1946), the archaeological documentation clearly suggests that in the course of the excavations, seventeen graves were registered in the field. The deceased, buried with skeletal rites, were arranged supine with their skeletons upright. Most of the deceased had their heads turned to the north-east (graves no. 4, 9, 10,11, 12, 13, 14), some to the south-west (graves no. $7,8,15,16,17$ ), to the east (grave no. 5), to the west (graves no. 1, 3) and to the north-west (grave no. 6). The bodies were buried 20 to $90 \mathrm{~cm}$ deep.

Notably, it is definitely not the ultimate number of burials identified in the presented necropolis. Information provided in an article by K. Jażdżewski suggests that Franciszek Stępiński, the field's owner, "had come across human skeletons when extending his yard by levelling a sandy hill; the skeletons had been accompanied by several iron knives, a bowl shaped on a potter's wheel and a spindle whorl" (Jażdżewski 1937, p. 127). What is more, the Warsaw SAM cards developed for some of the artefacts from the Morawy grave field provide information that the historic objects come from a damaged grave. These remarks refer to 
a clay spindle whorl $(\mathrm{SAM} / \mathrm{V} / 995 / 21)^{4}$, three iron knives (SAM/V/995/22; $\mathrm{SAM} / \mathrm{V} / 995 / 23 ; \quad \mathrm{SAM} / \mathrm{V} / 995 / 24)$ and pieces of an iron bucket hoop (SAM/V/995/25). Other artefacts which are not associated with any unit in the respective historic object cards, were probably discovered in graves. This pertains primarily to the clay bowl (SAM/V/995/27); the context of its discovery was clearly indicated by K. Jażdżewski ${ }^{5}$. The knife preserved in pieces (SAM/V/995/26), one of the clay utensils (SAM/V/995/28) ${ }^{6}$ and other numerous pieces of ceramic are less obvious cases. The context in which this group of artefacts was found remains a mystery.

We also know that some of the historic objects were registered loosely in the course of various excavations in the grave field. This is how the field owner, F. Stępiński, discovered a bronze, gold-plated knob (SAM/V/995/1) when digging in sand; he handed the artefact to S. Madajski (Musianowicz 1969, s. 355). Seven years after the archaeologist's research (Jażdżewski 1995, p. 104), right under the surface of the sand, in the vicinity of the formerly excavated grave field, Bonifacy Zielonka found two green glass beads, a silver wire pendant and a clay mug with a handle (Zielonka 1946). The location of the latter artefacts excavated by the archaeologist from Torun remains unknown. At the same time, it is impossible to determine if these artefacts came from previously damaged graves or perhaps unexplored ones.

Also in the 1980s, in the course of selling humus, an urn was discovered and allegedly transferred to Bydgoszcz? ${ }^{7}$. Then a layer of the ground was stripped off (thickness from $50 \mathrm{~cm}$ to $100 \mathrm{~cm}$ ) and sold for road building purposes, in order to level a hill mentioned by archaeologists before WWII (Jażdżewski 1937, p. 127).

The last information suggests that the pre-WWII farm and the contemporary buildings were located on the slope of a hill which was gradually and significantly levelled over several decades. A comparison of record parcel no. $38^{8}$ with parcel no. 45 as we know it today (which hosted the grave field) is evidence of prominent differences in the two fields' heights (Małkowski 2014). At the same time, oral information provided by the locals suggest that record parcel no. 45

4 Each time, I provide the inventory number from the historic object card developed for a specific artefact in the SAM in Warsaw. The historic object cards have been completed by archaeologists managed by Jan Loziński (1984) and A. Piotrowski (1992). On top of that, one of the cards describing a bronze, gold-plated knob, was completed in 1979.

5 See the previous quotation from the main text.

6 The clay utensils are discussed in detail further in the text.

7 The oral information provided by Helena Piazdecka, owner of record parcel no. 45 and daughter of the field owner in 1937. Unfortunately, in the course of search queries we did not manage to establish where the discovered urn was located.

8 The parcel is owned by Marcin Ogrodowski. In the $1930 \mathrm{~s}$, when archaeological excavations took place in the grave field, the land was owned by Stanisław Wiśniewski. 
bordering with parcel no. 38 was significantly higher ${ }^{9}$. The height situation now is completely reversed.

The site plan from 1937 (Figure 1) also indicates that in the past 79 years, the archaeological site underwent profound changes. In the 1970s, the site (record parcel no. 45) hosted a single-storey residential building with a basement, adjacent to S. Madajski's excavations. The structure was built to the north-east of the excavations. At the same time, a dirt road was shifted (record parcel no. 49) which is now located east of the borderline of S. Madajski's excavations. It is possible that these operations also involved damage to the graves. The picture of the transformations is complete in the light of a cutting provided for drains and a communications cable registered in the course of archaeological excavations in record parcel no. 45 in 2015 (Danielewski 2015).

All these operations have probably led to the complete exploration or damage to the grave field. In these circumstances, a detailed description of the excavations from 1937 seems even more desirable ${ }^{10}$.

\section{Grave no. 1}

According to the drawn documentation, an individual approximately $1 \mathrm{~m}$ tall was buried in the grave. The bone material was poorly maintained (parts of the long bones of the legs, the pelvic bones and the skull). The grave contained antiquities of significant value by the site's standards. Next to the skull of the deceased, beads were discovered. The drawing documenting the grave shows only six beads, while the SAM collection in Warsaw includes as many as fifteen glass beads related to this burial. These include one yellow bead, spindle-shaped and irregular (length: $1.4 \mathrm{~cm}$, diameter: $0.6 \mathrm{~cm}$; aperture diameter: $0.3 \mathrm{~cm}-\mathrm{SAM}$ / $\mathrm{V} / 995 / 2)^{11}$, four green, cylindrical beads: two whole ones and two in halves (height: approx. $0.4 \mathrm{~cm}$, diameter: approx. $0.4 \mathrm{~cm}$, aperture diameter: $0.1-0.2 \mathrm{~cm}-$ $\mathrm{SAM} / \mathrm{V} / 995 / 3$ ), seven irregular, cylindrical beads (including one in pieces), black (height: $0.4 \mathrm{~cm}$, diameter: $0.45 \mathrm{~cm}$, aperture diameter: 0.1-0.2 cm - SAM/V/995/4), three irregular beads, grey and brown patina (height: $0.4 \mathrm{~cm}$, diameter: up to 0.6 cm, aperture diameter: up to $0.2 \mathrm{~cm}-\mathrm{SAM} / \mathrm{V} / 995 / 5)$. The collection was topped with one temple ring (preserved in pieces - SAM/V/995/6) with a diameter of approx. $2.5 \mathrm{~cm}, \mathrm{~S}$-shaped, made of tin with a round wire cross-section and a ham-

\footnotetext{
9 This information was provided by Zbigniew Kłos, a local of Dobre village who cultivated parcel no. 38 together with the then owner, Janusz Ogrodowski.

${ }_{10}$ Please note that the description is based on the results of archaeological excavations from 79 years ago and based on incomplete archaeological documentation. However, the materials at hand need to suffice to present the results of the excavations from 1937.

${ }^{11}$ All the artefacts' descriptions are provided with relation to the historic object cards collected at SAM in Warsaw, measurements and own observations of the artefacts in question.
} 
mered end coiled to form an eye. It is an S-shaped temple ring type III (variety B). Unfortunately, its location in the grave is unknown.

\section{Grave no. 2}

This is one of the most interesting burials discovered in the grave field and the best described one. At a depth of barely $25 \mathrm{~cm}$, pieces of a clay utensil were discovered, among them human bones. There are indications in the literature on the subject that it was a young individual aged approximately 10 (Zoll-Adamikowa 1975, p. 175). The age was identified by archaeologists on the basis of the undersized teeth, scarce bone material and thin skull bones. Among the bones were also pieces of charcoal (Jażdżewski 1937, p. 128). The anthropological material and the ceramic were scattered in an area approx. $20 \mathrm{~cm}$ wide and approx. $30 \mathrm{~cm}$ long.

The remains should be referred to a receptacle marked by K. Jażdżewski as no. 2 on Figure 1 (Jażdżewski 1937, p. 127 fig. 1; Zoll-Adamikowa 1975, p. 176). On the other hand, Z. Rajewski (Rajewski 1958, p. 198 fig. 2) erroneously indicated the utensil from grave no. 2 as an urn; it is a utensil with a cylindrical neck and a slanted ornament of a triple comb imprinted where the body merges into the neck (SAM/V/995/29). The utensil, described by the above mentioned archaeologist, was located in grave no. 15 as indicated by the drawing and photographic documentation.

The urn in which the remains were found, however incomplete, was presented by K. Jażdżewski as a reconstructed artefact. At present, the receptacle (preserved in pieces), can be found in the Storage and Study Facilities in Rybno. The urn was shaped on a potter's wheel and smoothed from the outside and the inside along its entire height. It also has an ornament in the form of all-round grooves on the entire surface of the utensil. The admixture includes fine-grained and medium-grained crushed stone; the bottom does not reflect any potter's marks. As the urn has been preserved in pieces, the dimensions cannot now be accurately identified $^{12}$.

It is worth adding that the described grave corresponds well with the oral information about discovering another ash container in the 1980s (dated tentatively back to the $11^{\text {th }}$ century). These excavations are an indication that the grave field in Morawy was bi-ritual.

\footnotetext{
${ }^{12}$ In my opinion, the urn requires reconstruction/re-modelling in order to determine its complete dimensions.
} 


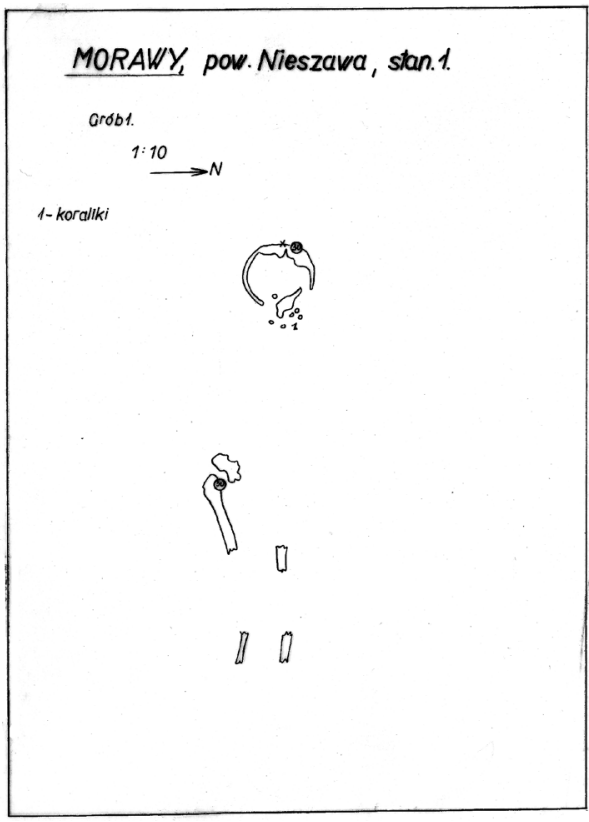

Fig. 3. Drawings of graves no.1, Morawy site 1.SAM Warsaw collection

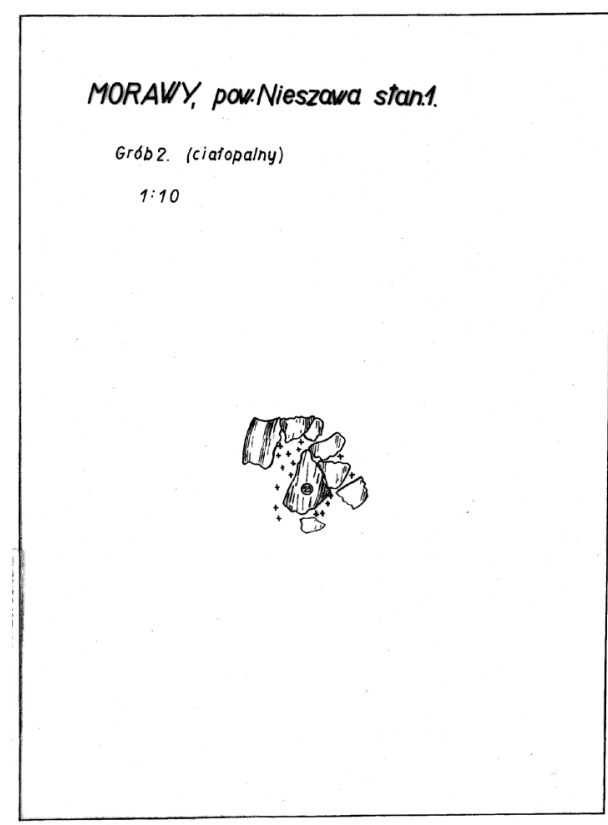

Fig. 4. Drawings of graves no. 2, Morawy site 1.SAM Warsaw collection

\section{Grave no. 3}

A burial without antiquities; the preserved bones include only the skull and teeth. Perhaps in this case the buried individual was young, as indicated tentatively by the drawn documentation.

\section{Grave no. 4}

There is no drawing or photographic documentation of the grave. No artefacts discovered in the grave.

\section{Grave no. 5}

The deceased discovered in the grave was approximately $180 \mathrm{~cm}$ tall. The bone material was quite well preserved, bearing in mind the remaining burials from the Morawy grave field. Parts of the long bones of the arms and legs have been preserved together with the feet bones, the skull, the pelvic bones, the right collar 


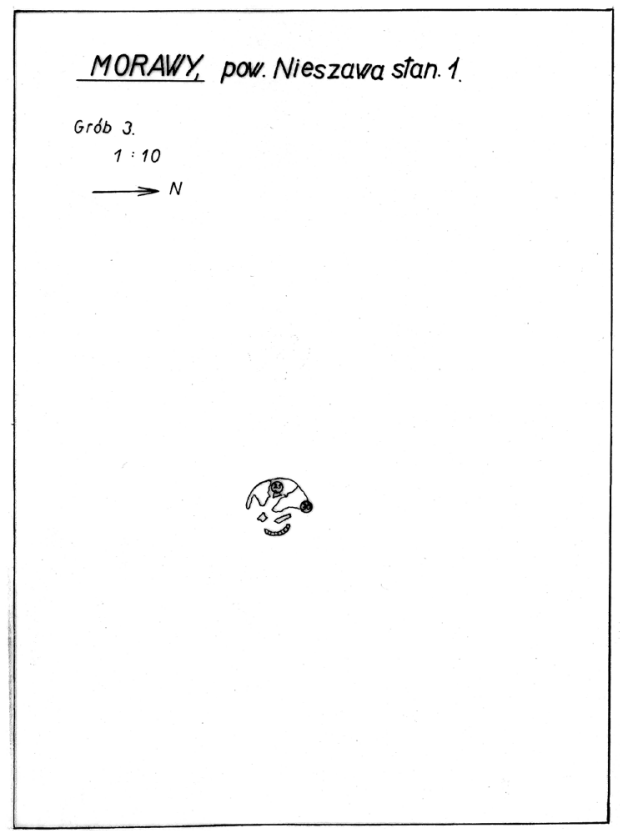

Fig. 5. Drawings of graves no. 3, Morawy site 1.SAM Warsaw collection

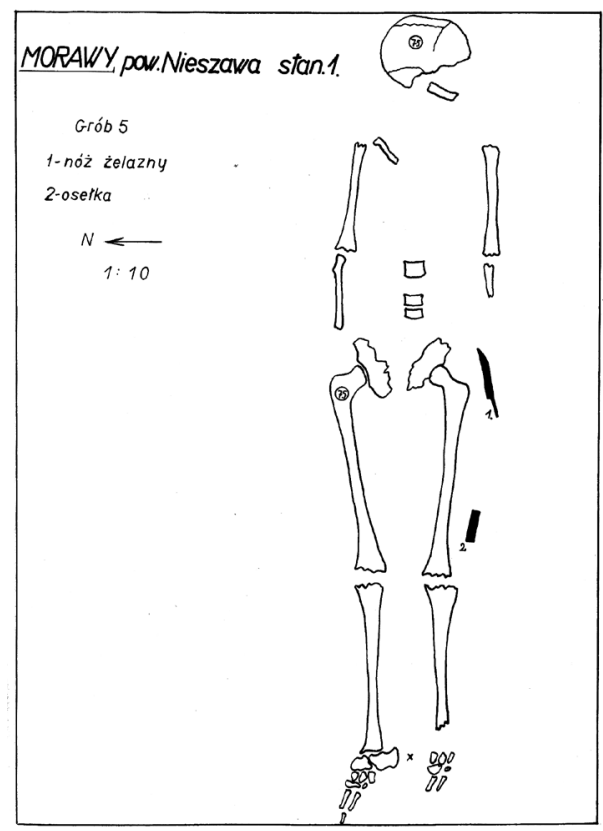

Fig. 6. Drawing of grave no. 5, Morawy site 1.SAM Warsaw collection

bone and three vertebrae. An iron knife was located next to the left femur and the pelvis; a slate sharpening stone was located closer to the knee. Sadly, the SAM Warsaw collection of the artefacts from S. Madajski's excavations does not include the aforementioned knife. However, the museum stores a slate sharpening knife (SAM/V/995/7), trapezium-shaped with an aperture to hang it. The upper end of the stone is chipped and bears traces of frequent use. The sharpening stone is 5-6 cm long, $1.3-1.7 \mathrm{~cm}$ wide and $0.55 \mathrm{~cm}$ thick.

\section{Grave no. 6}

A burial without antiquities. The grave contained a deceased person approximately $165 \mathrm{~cm}$ tall with partly preserved long bones of the legs, the right foot, the skull and two vertebrae. 


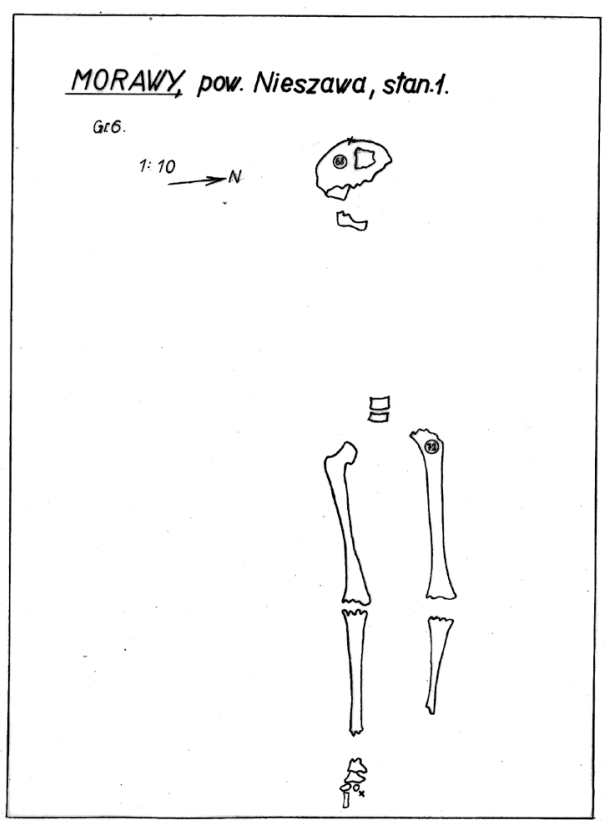

Fig. 7. Drawing of grave no. 6, Morawy site 1.SAM Warsaw collection

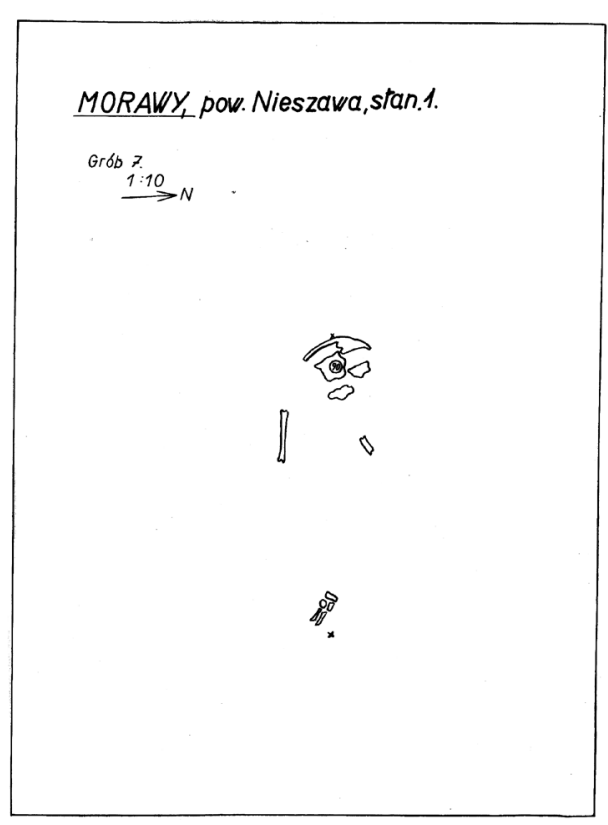

Fig. 8. Drawing of grave no. 7, Morawy site 1.SAM Warsaw collection

\section{Grave no. 7}

A burial without antiquities. The grave contained a young individual approximately $65 \mathrm{~cm}$ tall with partly preserved long bones of the arms, a foot and the skull.

\section{Grave no.8}

A burial without antiquities. The grave contained a deceased approximately $140 \mathrm{~cm}$ tall with partly preserved long bones of the legs, the right arm, the skull with teeth and the pelvic bones.

\section{Grave no. 9}

The grave contained a body of an individual slightly more than $155 \mathrm{~cm}$ tall. The preserved bones included parts of the long bones of the arms and legs, the skull and two vertebrae. An iron knife (SAM/V/995/8) was found in the grave near the left forearm. It has survived in two pieces. It is a knife with a one-sided tang 


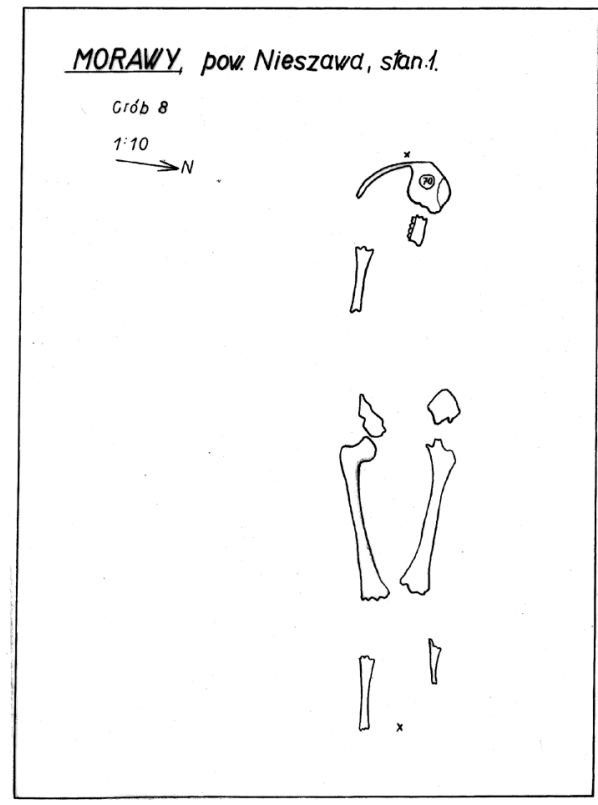

Fig. 9. Drawing of grave no. 8, Morawy site 1.SAM Warsaw collection

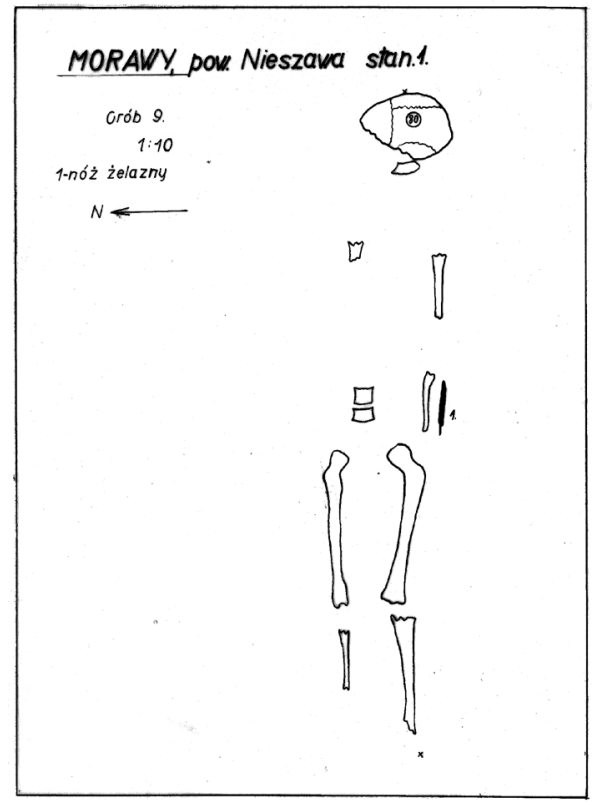

Fig. 10. Drawing of grave no. 9, Morawy site 1.SAM Warsaw collection

and a straight blade with a broken tip. The object is $10.6 \mathrm{~cm}$ long (the longer side has $6.3 \mathrm{~cm}$, the shorter one $4.3 \mathrm{~cm}$ ), approximately $1.2 \mathrm{~cm}$ wide, the thickness of the pommel amounting to $0.3 \mathrm{~cm}$ and the tang length to $1.4 \mathrm{~cm}$.

\section{Grave no. 10}

A burial without antiquities. In the grave, the remains were discovered of an individual approximately $160 \mathrm{~cm}$ tall with partly preserved long bones of the legs and arms, the skull and teeth, the pelvic bones, the feet, the right collar bone and six vertebrae.

\section{Grave no. 11}

There is no drawing or photographic documentation of the grave. No artefacts discovered in the grave. 


\section{Grave no. 12}

There is no drawing or photographic documentation of the grave. However, two iron knives were discovered next to the deceased. One of them (SAM/V/995/9) had a straight pommel and blade as well as a tang separated on both sides. The knife was $15.1 \mathrm{~cm}$ long and up to $1.4 \mathrm{~cm}$ wide. The pommel was $0.3 \mathrm{~cm}$ thick while the tang was $4.5 \mathrm{~cm}$ long. The other knife (SAM/V/995/10) was slightly worse preserved. Its tang was also separated on both sides, the blade was straight and the pommel arched. The knife was $8.9 \mathrm{~cm}$ long and the maximum width was $1 \mathrm{~cm}$. The thickness of the pommel was $0.4 \mathrm{~cm}$ and the length $0.9 \mathrm{~cm}$.

\section{Grave no. 13}

There is no drawing or photographic documentation of the grave. However, an iron knife was discovered next to the deceased (SAM/V/995/11). The object has survived in three pieces of total length amounting to $10.6 \mathrm{~cm}$ and width of 1.7 $\mathrm{cm}$. The pommel and the blade are straight while the tang is one-sided and strongly bent upwards on the blade's side. The pommel's thickness amounts to $0.5 \mathrm{~cm}$ and the tang's length to $1.8 \mathrm{~cm}$.

\section{Grave no. 14}

There is no drawing or photographic documentation of the grave. No artefacts discovered in the grave.

\section{Grave no. 15}

The grave contained a deceased whose height slightly exceeded $145 \mathrm{~cm}$. The bone material included the long bones of the left leg and parts of the right one, parts of the left arm, the skull, the left collar bone and the right pelvic bone as well as ten vertebrae. On the right side of the grave an iron knife was found $(\mathrm{SAM} / \mathrm{V} / 995 / 12)$. The object was $5.8 \mathrm{~cm}$ long and maximum $0.7 \mathrm{~cm}$ wide. The knife's pommel and blade were straight while the tang was one-sided and slightly bent downwards. The thickness of the pommel was $0.3 \mathrm{~cm}$ and the tang's length amounted to $2.4 \mathrm{~cm}$.

A clay utensil (SAM/V/995/29) was found in the grave, hand-shaped on a potter's wheel and smoothed on the outside and inside along the entire height. It has an ornament of all-round grooves on the neck and in the middle part of the body. What is more, the utensil is decorated with a slanting triple comb imprinted 


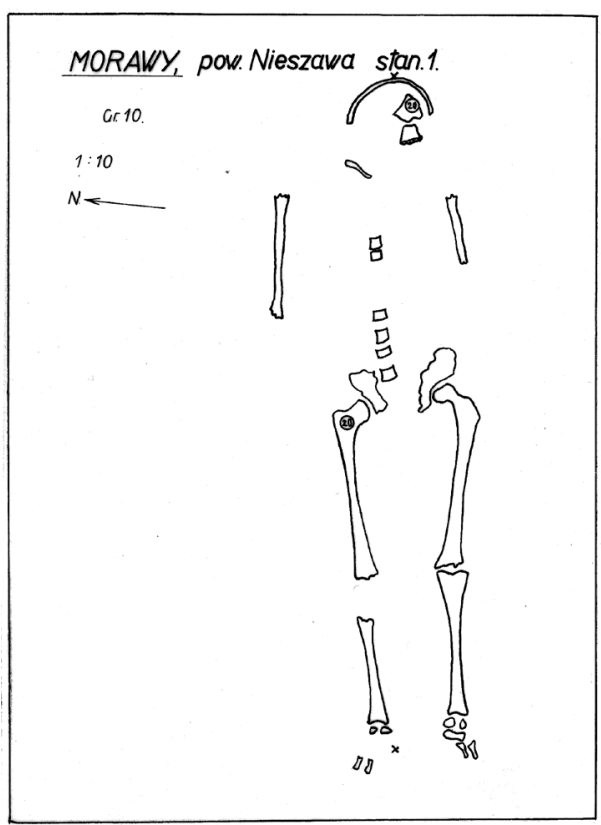

Fig. 11.

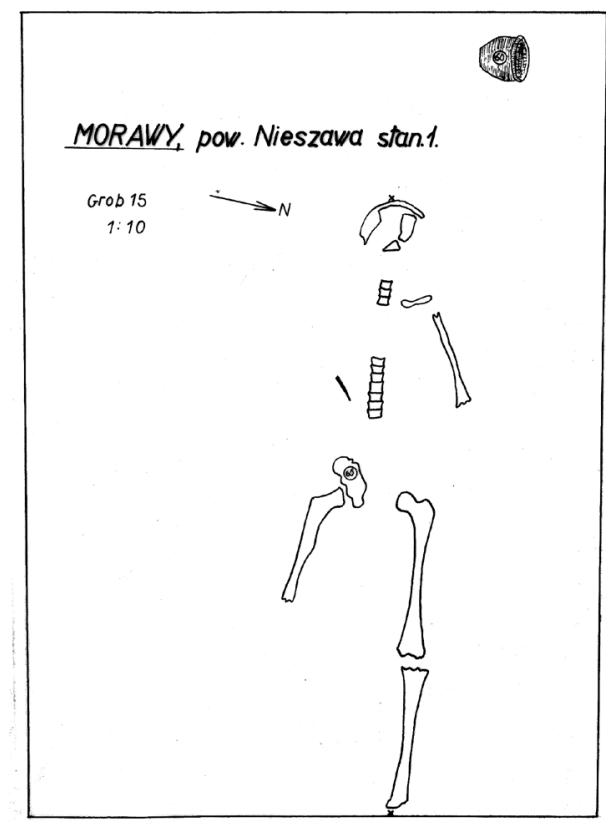

Fig. 12. Drawing of grave no. 15, Morawy site 1.SAM Warsaw collection

where the body merges into the neck. The admixture includes fine-grained, medium-grained and small amounts of coarse-grained crushed stone. The utensil is 10.25 $\mathrm{cm}$ high, the body's maximum circumference is $13 \mathrm{~cm}$, the walls are $0.8-1 \mathrm{~cm}$ thick and the bottom is $0.75 \mathrm{~cm}$ thick.

\section{Grave no. 16}

There is no drawing or photographic documentation of the grave. An iron knife was found with the deceased, preserved in four pieces (SAM/V/995/13).

\section{Grave no. 17}

The skeleton excavated in the grave was probably that of a woman; the antiquities seem to support the hypothesis. The preserved bone material includes the long bones of the right leg and the left one partially, the right arm partially and the skull with teeth.

The grave is undoubtedly the richest in the Morawy grave field with respect to antiquities. Pieces of black fabric were discovered there (SAM/V/995/14) with im- 


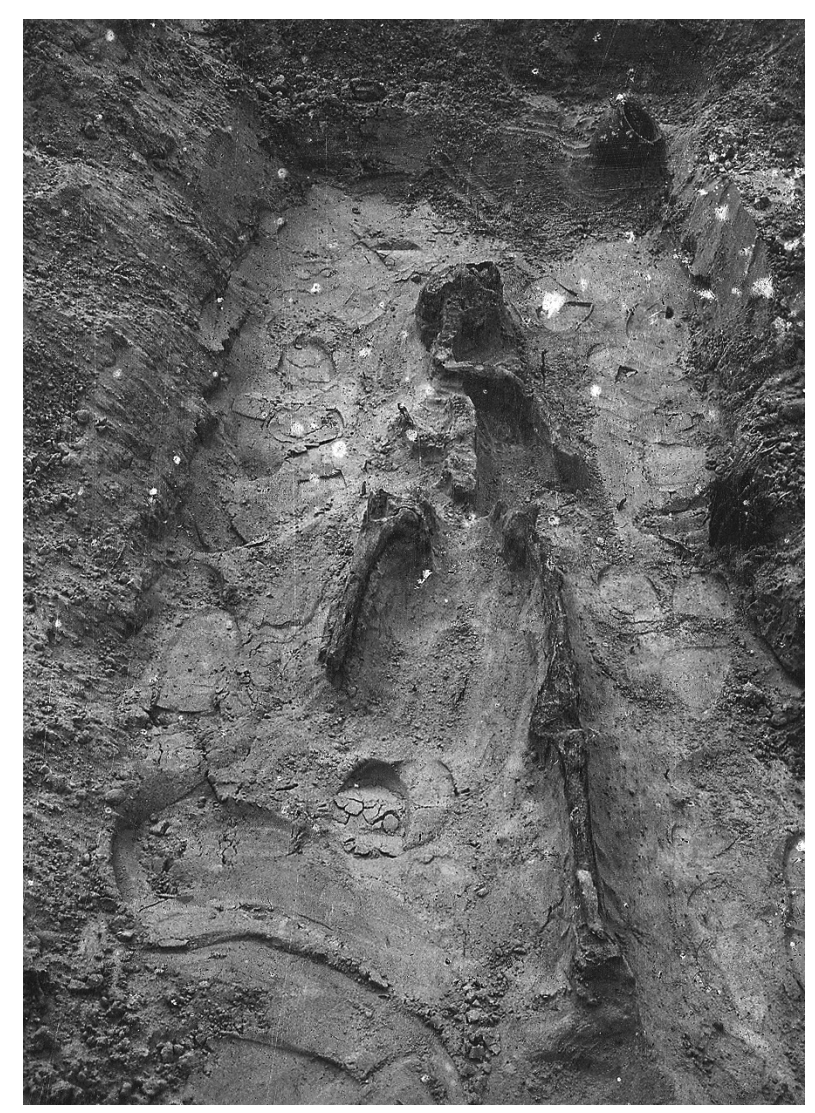

Fig. 13. Photograph of grave no. 15, Morawy site 1.SAM Warsaw collection

prints of two temple rings. On top of that, the grave contained six temple rings. One of them (SAM/V/995/15) was made of bronze and was silver-plated. This S-shaped ring has a very characteristically hammered end coiled to form an eye through which a ribbed ribbon was rolled into two eyes. The diameter of the object amounts to $2.4 \mathrm{~cm}$. Another S-shaped temple ring (SAM/V/995/16) was also made of silver-plated bronze. One end is closed with a coiled eye. The ring's diameter is $2.3 \mathrm{~cm}$. A third specimen (SAM/V/995/17) was made of the same material as the former two rings. One of its ends also has an eye. The ring's diameter amounts to $2.3 \mathrm{~cm}$. All these rings are S-shaped temple rings, type III (variety B).

The subsequent three rings (SAM/V/995/18, SAM/V/995/19, SAM/V/995/20) have been preserved in small pieces (the first ring in twelve pieces, the second in two pieces, the third in eight pieces). Interestingly, they are made of tin. 
A photograph illustrating grave no. 17 shows that the temple rings were discovered to the right of the head and next to the right arm. The picture shows at least four rings, including a piece of one of them.

Notably, there is no lead ring among the excavations, contrary to what the literature on the subject suggested (Jażdżewski 1937, p. 127 fig. 1, 128). Most probably, one of the tin rings which is now in pieces had been identified as a lead ring. This seems even more probable in the light of the fact that the most characteristic temple ring with an end coiled in an eye with the ribbed ribbon forming two eyes was identified as a bronze ring (Jażdżewski 1937, p. 127 fig. 1, 128). It is known for a fact now that it is silver-plated as the surface shows.

\section{HISTORIC OBJECTS FROM A DAMAGED GRAVE}

It remains an open question if the historic objects described below come from one grave. The issue cannot possibly be solved in light of the existing documentation of the excavations carried out in the grave field in question. These artefacts include, among other things, a clay two-cone spindle whorl (SAM/V/995/21). It is smoothed and has an ornament of all-round grooves. The spindle whorl is $2.4 \mathrm{~cm}$ high, has a diameter of $2.9 \mathrm{~cm}$ and the aperture's diameter is $0.9 \mathrm{~cm}$.

On top of these artefacts, three iron knives were discovered in the damaged grave(s). One of the knives (SAM/V/995/22) was $9.9 \mathrm{~cm}$ long and its maximum width amounted to $1.3 \mathrm{~cm}$. The knife had a straight pommel and blade while the tang was one-sided, $2.3 \mathrm{~cm}$ long. The pommel's thickness amounted to $0.4 \mathrm{~cm}$. The knife broadened towards the end which was broken. Another knife (SAM/V/995/23) has been preserved without the tang; it is $7.8 \mathrm{~cm}$ long and 0.9 $\mathrm{cm}$ wide. The $0.3 \mathrm{~cm}$ pommel is slightly arched on the side of the chipped tang. The blade is similarly arched. The third knife (SAM/V/995/24), $10.4 \mathrm{~cm}$ long and $0.9 \mathrm{~cm}$ wide, has a characteristic one-sided tang, an arched blade and a pommel arched on the side of the tang. Its length amounts to $3.2 \mathrm{~cm}$ and the pommel is $0.3 \mathrm{~cm}$ thick.

In the damaged grave(s) pieces of a bucket hoop were also identified (SAM/V/995/25). This type of objects was also discovered in other grave fields from the $11^{\text {th }}$ century. A case in point is a necropolis in Sowinki in Wielkopolska region dated back, among other times, to the $11^{\text {th }}$ century (Krzyszowski 1992, p. 90-91, 96, 99) or the grave field in Brześć in Kuyavia (Byrska-Kaszewska 1957, pp. 391-393, 399). The pieces of the pail loop were $19 \mathrm{~cm}$ long, $0.5 \mathrm{~cm}$ wide and $0.3 \mathrm{~cm}$ thick. 


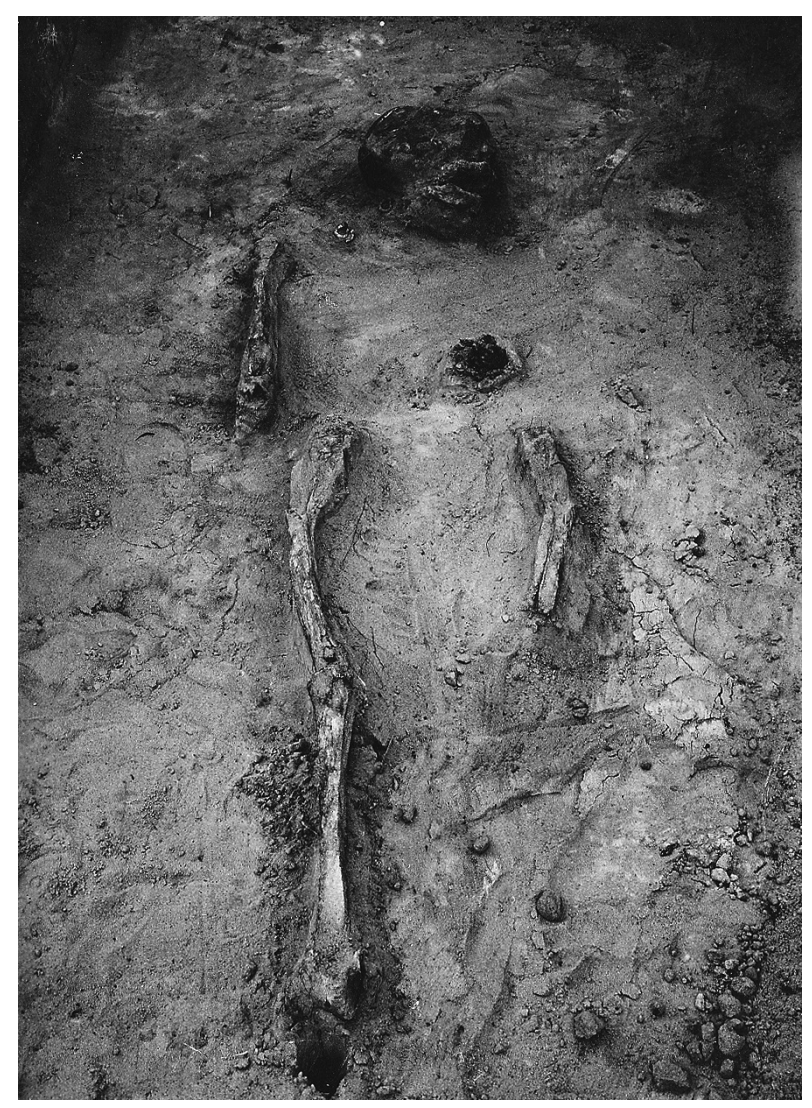

Fig. 14. Photograph of grave no. 17, Morawy site 1.SAM Warsaw collection

\section{HISTORIC OBJECTS OF UNIDENTIFIED LOCATION, DISCOVERED LOOSE}

The historic objects of unidentified location include an iron knife preserved in pieces (SAM/V/995/26) and clay utensils. One of them (SAM/V/995/27) is a bowl made on a potter's wheel, smoothed from the inside and the outside along the utensil's entire length. On the bottom of the bowl is a potter's mark in the form of an even-armed cross: group I, sub-group Ia (Dzieduszycki 1982, p. 56, 195). The admixture includes fine-grained, medium-grained and small amounts of coarsegrained crushed stone. The utensil is $4.5 \mathrm{~cm}$ high, the body's maximum circumference amounts to $13.6 \mathrm{~cm}$, the walls are 0.9 to $1.1 \mathrm{~cm}$ thick while the bottom is $0.8 \mathrm{~cm}$ thick.

The other utensil (SAM/V/995/28) was also made on a potter's wheel and smoothed along the entire height on the outside and the inside. It is decorated with 
broad, all-round grooves on the neck and the upper part of the body. Moreover, on the bottom of the utensil a potter's mark is imprinted in the form of an evenarmed cross inscribed in a circle: group I, sub-group Ib (Dzieduszycki 1982, p. 56, 196). The admixture includes fine-grained and medium-grained crushed stone. The utensil is $14.45 \mathrm{~cm}$ high, the body's maximum circumference amounts to $15.6 \mathrm{~cm}$, the walls are $0.6-0.8 \mathrm{~cm}$ thick and the bottom is $0.65 \mathrm{~cm}$ thick.

Notably, according to the descriptions in the historic objects' cards, the utensils were discovered in the course of S. Madajski's excavations in 1937. This fact is not so solid in the case of the above mentioned pieces of the knife.

The pieces of a utensil, now stored in the Storage and Study Facilities in Rybno in one box together with the bone material from grave no. 14, pose another problem and lead to the question of whether the ceramic material was discovered in the grave or maybe it was registered elsewhere? This doubt is impossible to clarify, especially that there is no preserved drawing or photographic documentation for grave no. 14. On the other hand, the ceramic clearly has common features with the remaining utensils discovered in the grave field. It is a utensil shaped on a potter's wheel, smoothed on the inside and the outside along its entire height. It has a characteristic ornament of all-round grooves on its whole surface. The admixture includes fine-grained, medium-grained and small amounts of coarse-grained crushed stone; there are no potter's signs on the bottom. At present, it is impossible to reconstruct the dimensions of the utensil due to the fact that it has been preserved in pieces.

The last historic object from the Morawy collection worth mentioning is half of a gold-plated bronze knob. This object was discovered loose in the field when F. Stępiński, the field's owner, was digging in the sand (Musianowicz 1969, s. 355). This is the most elite object registered on site no. 1. The exact stratigraphic context in which the object was discovered remains unknown. This fact reduces the artefact's cognitive value.

The knob in question has been described in detail in literature on the subject (Musianowicz 1969, p. 355-356). Therefore, there is no need to repeat this information. The artefact's origin is interesting: the knob has been attributed to the south-east of Moravia, possibly Nitra. That would correspond with Morawy, the name of the village and a captive settlement. At the same time, the knob should be dated back to the second half of the $10^{\text {th }}$ century (Musianowicz 1969, p. 358-359).

To date, literature on the subject dated the grave field to the $11^{\text {th }}$ century (Jażdżewski 1937, p. 129; Zoll-Adamikowa 1975, p. 175). K. Musianowicz slightly narrowed down this chronology: in her opinion, the grave field could be dated back to the second half of the $11^{\text {th }}$ century (Musianowicz 1969, p. 358). The question remains if this chronology could be more precise. Let me first present the historic objects which may suggest the date of origin of the site in question. In this respect, ceramic objects will be taken into consideration together with temple rings and the gold-plated knob. 
The knob is the least complicated to define in time. As I have already mentioned, scholars date it back to the second half of the $10^{\text {th }}$ century (Musianowicz 1969 , p. 358). In this case, one should make an assumption that historic object made its way to the village of Morawy and was still in use in the $11^{\text {th }}$ century.

The ceramic discovered on the site seems to offer much better dating opportunities. On the basis of a utensil from urn grave no. 2, K. Musianowicz suggested to date the grave field back to the second half of the $11^{\text {th }}$ century. In my opinion, this is the right suggestion. The Morawy ceramic displays analogies with the ceramic material from the grave field in Brześć Kujawski (site no. 5). The latter has been quite well described (Byrska-Kaszewska 1957, p. 393-395). The similarities in the production technology, the ornamentation, the admixture or the emergence of potter's marks all indicate that the Morawy necropolis can be dated back to the second half of the $11^{\text {th }}$ century. The only differences lie in the sizes of the utensils. The utensils discovered in Brześć Kujawski were smaller than the ones from Morawy. In this case, the Brześć ceramic would be destined for the grave (Byrska-Kaszewska 1957, p. 394-395). The potter's marks are also an important detail in the ceramic discovered in the Morawy grave field. They are evidence that pottery must have been well developed in the region, and the local potters used their own marks. In this respect, they correspond well with the potter's marks from Kruszwica; the ceramics discovered in the gord and the open helmets from that time had numerous, similar marks (Dzieduszycki, 1982, p. 56, 195, 196).

The temple rings are another important date reference, albeit not as sensitive as the ceramic. In total, seven rings were discovered in the grave field while only four of them (the S-shaped, type III, variety B rings) can be classified more precisely. These accessories emerged sporadically in the late $10^{\text {th }}$ century. However, in the Wielkopolska region they made an appearance chiefly in the $11^{\text {th }}-13^{\text {th }}$ centuries (Kóčka-Krenz 1993, p. 49). This chronology is broad but in reference to the ceramics, it may indicate that the grave field operated in the second half of the $11^{\text {th }}$ century.

Research into the chronology of the grave field could be extended with the results of radiocarbon dating, the AMS (accelerator mass spectrometry) method. However, to a large extent, the bone material from the grave field is preserved in pieces. Therefore, only bones from cremation grave no. $2^{13}$ were selected for such analyses. The results seem extremely interesting because there is $40.7 \%$ probability that the burial took place in $1045-1095^{14}$. This seems to confirm the accuracy of the conventional dating.

13 The material for the radiocarbon dating was collected by Artur Dębski, MA, one of the team members of project no. 0040/NPRH3/H11/82/2014 .

14 The remaining timeframes are as follows: $1120-1142(17.1 \%)$ and 1147-1160 (10.4\%). However, for $95.4 \%$ probability, the grave can be dated back to 1030-1189; bearing in mind such a wide chronological framework, the result is of little value. 
The discussed site no. 1 in Morawy village is among the most interesting grave fields in Kuyavia dated back to the early Middle Ages. The necropolis is not as elite as the other Kuyavia grave fields in Brześć Kujawski or Bodzia. The latter grave field is dated back to the late $10^{\text {th }}$ and the early $11^{\text {th }}$ centuries (Buko, Kara, Douglas Price, Duczko, Margarita Frei i Sobkowiak-Tabaka 2013, pp. 432-434; Kara 2013, p. 117). In fact, graves no. 1 and $17^{15}$ which would be deemed elitist by the Morawy necropolis standards, would not make a statement in the Brześć or Bodzia grave fields with their sets of discovered artefacts. It is worth emphasizing that the mentioned fields differ significantly with respect to the number of the discovered graves. At the same time, the extent to which site no. 1 in Morawy has been identified indicates that originally, the necropolis could have been much larger. Of course, the Morawy grave field is among the less affluent ones by Kuyavia standards. However, the Morawy necropolis also contained elite historic objects like the bronze, gold-plated knob or bronze, silver-plated temple rings. It seems, however, that with respect to the antiquities, the grave field in question connects well with the hypotheses put forward by Z. Rajewski and K. Musianowicz about the captive background of the population buried in Morawy. It is hard to expect captives to have at their disposal extremely elite objects to place in graves. The grave field in question is therefore an interesting example of an alleged captive settlement in the Piast dynasty's domain.

Table 1. Graves discovered in the Morawy grave field (site 1), divided with respect to the antiquities and the drawn and photographic documentation

\begin{tabular}{|c|c|c|c|}
\hline \multicolumn{2}{|c|}{ Graves } \\
\hline \multicolumn{2}{|c|}{ Graves with antiquities } & \multicolumn{2}{c|}{ Graves without antiquities } \\
\hline $\begin{array}{c}\text { Graves with drawing or } \\
\text { photographic documenta- } \\
\text { tion }\end{array}$ & $\begin{array}{c}\text { Graves without drawing } \\
\text { or photographic } \\
\text { documentation }\end{array}$ & $\begin{array}{c}\text { Graves with drawing or } \\
\text { photographic documenta- } \\
\text { tion }\end{array}$ & $\begin{array}{c}\text { Graves without drawing } \\
\text { or photographic } \\
\text { documentation }\end{array}$ \\
\hline Grave no. 1 & Grave no. 12 & Grave no. 3 & Grave no. 4 \\
\hline Grave no. 2 & Grave no. 13 & Grave no. 6 & Grave no. 11 \\
\hline Grave no. 5 & Grave no. 16 & Grave no. 7 & Grave no. 14 \\
\hline Grave no. 9 & & Grave no. 10 & \\
\hline Grave no. 15 & & & \\
\hline Grave no. 17 & & & \\
\hline
\end{tabular}

${ }^{15}$ I have disregarded the damaged grave because it remains uncertain if the following objects: a clay spindle whorl, three iron knives and two pieces of a pail iron hoop, come from a single grave. 
Table 2. Graves with described antiquities

\begin{tabular}{|c|c|c|}
\hline \multicolumn{3}{|c|}{ Graves } \\
\hline $\begin{array}{l}\text { Graves with } \\
\text { antiquities }\end{array}$ & Type of antiquities & Graves without antiquities \\
\hline Grave no. 1 & $\begin{array}{l}\text { - fifteen glass beads (including four in pieces) } \\
\text { - a temple ring made of tin (in pieces) }\end{array}$ & Grave no. 3 \\
\hline Grave no. 2 & - urn & Grave no. 4 \\
\hline Grave no. 5 & - slate sharpening stone & Grave no. 6 \\
\hline Grave no. 9 & - iron knife (two pieces) & Grave no. 7 \\
\hline Grave no. 12 & - two iron knives & Grave no. 8 \\
\hline Grave no. 13 & - iron knife (two fitting pieces) & Grave no. 10 \\
\hline Grave no. 15 & $\begin{array}{l}\text { - clay utensil } \\
\text { - iron knife }\end{array}$ & Grave no. 11 \\
\hline Grave no. 16 & - iron knife (in pieces) & Grave no. 14 \\
\hline Grave no. 17 & $\begin{array}{l}\text { - piece of fabric with temple rings' imprints (probably } \\
\text { a ryasna) } \\
\text { - three silver-plated temple rings } \\
\text { - three tin temple rings (in pieces) }\end{array}$ & \\
\hline
\end{tabular}

Table 3. Historic objects discovered loose in the Morawy grave field or in damaged graves before S. Madajski's excavations (only historic objects stored in SAM in Warsaw have been considered)

\begin{tabular}{|l|l|}
\hline \multicolumn{2}{|c|}{ Historic objects from outside the grave complex described in detail } \\
\hline \multicolumn{1}{|c|}{$\begin{array}{c}\text { Historic objects from a damaged grave/ from damaged } \\
\text { graves }\end{array}$} & \multicolumn{1}{c|}{$\begin{array}{c}\text { Historic objects discovered loose or in unidentified } \\
\text { location }\end{array}$} \\
\hline $\begin{array}{l}\text { - clay spindle whorl, three iron knives, two pieces of } \\
\text { a bucket iron loop (all the artefacts could have come } \\
\text { from a single grave) }\end{array}$ & $\begin{array}{l}\text { - two clay utensils } \\
\text { - iron knife (in pieces) } \\
\text { - clay bowl } \\
\text { - golden-plated bronze knob } \\
\text { - loose ceramic material }\end{array}$ \\
\hline
\end{tabular}

\section{BIBLIOGRAPHY}

Buko A., Kara M., Douglas Price T., Duczko W., Margarita Frei K., Sobkowiak-Tabaka I. 2013, A unique medieval cemetery from the 10th/11th century with chamber-like graves from Bodzia (central Poland). Preliminary result of the multidisciplinary research, Archäologisches Korrespondenzblatt, 43, Heft 3, s. 423-442. 
Byrska-Kaszewska E. 1957, Cmentarzysko średniowieczne w Starym Brześciu powiat Włocławek (Stan. 4) cz. 1, Prace i Materiały Muzeum Archeologicznego i Etnograficznego w Łodzi. Seria Archeologiczna, 2, s. 85-124.

Danielewski M. 2014, Struktura grodowa w drugiej połowie XI wieku. Czy lata 30. XI wieku wyznaczaja przełom dla funkcjonowania organizacji grodowej $w$ Polsce, Historia Slavorum Occidentis 7, nr 2, s. $130-155$.

- 2015, Konary i Kobylniki. Rola i użytkowanie koni we władztwie Piastów, Historia Slavorum Occidentis, 8 , nr 1, s. 57-76.

- 2015b, Morawy stanowisko $n r$ 1, sprawozdanie z badań archeologicznych (obszar AZP 46-43) w 2015 roku. Zbiory Delegatury Wojewódzkiego Urzędu Ochrony Zabytków we Włocławku (DWUOZ).

Dzieduszycki W. 1982, Wczesnomiejska ceramika kruszwicka $w$ okresie od 2 połowy X w. po połowe $X I V$ w., Wrocław.

Hoff J. 1998, Dobre. Zarys dziejów do 1939 roku, Dobre.

Jażdżewski K. 1937, Interesujące zabytki z czasów piastowskich na Kujawach, „Z Otchłani Wieków”, 12, z. 9-10, s. 126-132.

Jażdżewski K. 1995, Pamiętniki. Wspomnienia polskiego archeologa z XX wieku, Łódź.

Kara M. 2013, Wybrane groby z uzbrojeniem z cmentarzyska w Bodzi pod Włocławkiem - przyczynek do studiów nad obecnościa ,, wikingów” w państwie pierwszych Piastów, w: T. Sawicki red., Studia nad dawna Polska, t. 3, Gniezno, s. 117-132.

Kolberg O. 1962, Kujawy, cz. I, Wrocław-Poznań.

Kosmas, 1923, Die chronik der Böhmem des Cosmas von Prag, lib. II, w: MGH SRG s.n., t. 2, ed. W. Weinberger, B. Bretholz, Berlin.

Kozierowski S. 1922, Badania nazw topograficznych na obszarze dawnej zachodniej i środkowej Wielkopolski, t. 2, Poznań.

Kóčka-Krenz H. 1993, Biżuteria pótnocno-zachodniostowiańska we wczesnym średniowieczu, Poznań.

Krzyszowski A. 1992, Wstepne wyniki badań archeologicznych na wczesnośredniowiecznym cmentarzysku szkieletowym z X/XI-XII wieku w miejscowości Sowinki, gm. Mosina, woj. poznańskie, Stanowisko 23A, Wielkopolskie Sprawozdania Archeologiczne, 1, s. 83-102.

Małkowski W. 2014, Sprawozdanie z badań nieinwazyjnych stanowiska $n r 1 \mathrm{w}$ miejscowości Morawy gm. Dobre, pow. radziejowski, woj. kujawsko-pomorskie. Zbiory Instytutu Archeologii UAM w Poznaniu.

Modrzewska H. 1969, Osadnictwo jenieckie we wcześniejszym średniowieczu polskim, „Kwartalnik Historii Kultury Materialnej”, 17, nr 3, s. 345-384.

Modzelewski K. 2000, Organizacja gospodarcza państwa piastowskiego X-XIII wiek, wyd. 2, Poznań.

Musianowicz K. 1969, Guz ze wsi Morawy, pow. Radziejów, „Wiadomości Archeologiczne” 35, z. 3-4, s. $355-360$.

Obszar 46-43, woj. włocławskie. Zestawienie treści kulturowej i chronologicznej stanowisk. Zbiory DWUOZ we Włocławku.

Повесть временных лет 1950, translated by Д.С.Лихачев, Б.А. Романов, Moskwa.

Rajewski Z. 1958, O wczesnośredniowiecznych grobach popielnicowych w Wielkopolsce i na Kujawach, Wiadomości Archeologiczne 25, z. 3, s. 197-201.

Thietmar, 1935, Die Chronik des Bischofs Thietmar von Merserburg und ihre Korveier Überarbeitung, w: MGH SRG n.s. IX, ed. R. Holtzmann, Berlin.

Zielonka B. 1946, Morawy. Przedhistoryczna osada palowa w Morawach gm. Sędzin, pow. nieszawski. Zbiory DWUOZ we Włocławku.

Zoll-Adamikowa H. 1975, Wczesnośredniowieczne cmentarzyska ciałopalne Stowian na terenie Polski, cz. 1, Wrocław. 